of the family had suffered from sore-throat, and diphtheria was hardly known in the district.

Later (in 1896) I inquired into another outbreak of roup in this district. In this outbreak hens and pigeons were attacked and the death-rate had been high and chiefly among young birds. None of the family had suffered from sore-throat and diphtheria was hardly known in the district.

Morbid anatomy.-The following particulars may be taken as typical of the conditions found in all the outbreaks. One bantam hen standing about, or walking lazily when aroused, I examined carefully. The mouth was red, swollen, and highly inflamed, and at the angle on one side was a piece of sloughing tissue which I removed, and part of which I examined under the microscope after staining with picrocarmine solution. The epithelium was healthy in some parts, while in others it showed a granular disintegration. Large cells with one, two, or three nuclei were also seen in the field and some of the cells showed nuclei almost extruded. The mouth contained on certain parts of its surface a fine membrane, a bacteriological description of which follows. The bird from which these specimens were obtained had a very unhealthy appearance, but it emitted no roupy noise. In another hen-run one bird which made a very roupy noise was examined. The mouth was congested and covered with a whitish sticky membrane. The entrance to the air-passages was deeply congested and swollen and this latter probably accounted for the roupy noise. In other birds the membrane was tough, whitish-grey, and possessed a foul odour; in others the mouth, nostrils, gullet, and entrance to the windpipe were deeply injected and were covered by a yellowish tough membrane; in others, again, the eyes appeared to suffer severely. In none of the cases was any paralysis observed, but this may have been owing to the rapidity of the fatal result.

Bacteriology of the membrane.-Without entering into details one may say that a micro.organism was found which after the most careful observations could not be distinguished from the Klebs-Löffler bacillus. But it cannot have been a virulent microbe, for the persons handling the affected fowls and without any special precautions did not directly contract the disease. This is an important point, for although, morphologically, the microbe isolated could not be distinguished from the micro-organism of true human diphtheria yet it did not seem to set up the disease in those brought into close contact with it. Further, it must be stated that a bacillus resembling the Klebs-Löffler micro-organism has been found in the mouth of healthy fowls. ${ }^{1}$ On the other hand, it must also be stated that according to many reliable observers the Klebs-Löffler bacillus (or one morphologically indistinguishable from it) is often found in the throats of perfectly healthy people. ${ }^{2}$

Conclusions and deductions.-1. Roup-like diphtheria (including the somewhat indefinite term "croup") varies in its malignancy, sometimes being mild with only one or two deaths in a large hen-run, while the next epidemic may almost clear out the whole coop. 2. The disease does not appear to be transmissible to man, for those handling the affected birds without any precautions do not suffer from any disease resembling diphtheria. 3. Paralysis was, according to $\mathrm{my}$ observations, absent in roup cases. 4. The disease is evidently a highly contagious catarrh and may correspond to the morve or fowl glanders of the French. ${ }^{3}$ 5. Roup probably differs entirely from "fowl diphtheria," so called. 6. As we have already seen, bird fanciers distinguish between a "dry" roup and a "wet" roup. Dry roup is most likely a simple benign catarrh corresponding to the recurring croup affecting children, especially those inhabiting valleys and near a river bank. Wet roup, on the otber hand, in its malignancy resembles diphtheria and

1 Dr. Allan MacFadyen and Dr. Hewlett, Brit. Med. Jour., April 21st, $1900, \mathrm{p}$ 494.

2 Park and Beebe, quoted by Osler, Principles and Practice of Medicine, second edition, pp. 103 and 104. O hers have also discovered the microbes in throats which were apparently bealtby.

$3 \mathrm{M}$. Gallez fils made a report to the Belgian Academy of Medicine on "The Relation of Diseases of Fowls to Diphtheria." I have not on "The Relation of Diseases of Fowls to Diphtheria." I have not seen the report itsalf but the following summary of it is given in THE discer of Aprll 18th, $1896, p$. 1082 . "There are two perfectly distinct talse to wheh such birds as domestic fowls are subject. First a conglary catarn, callen also inorve or fowl glanders, characterised by a elairy seorotion for the muous e es. alo also by rapld emalation and paraly human far los sulect. Its pris cause is a baeillus simllar to Lohler's but known as fowl ...... This disease differs from the second one which is known as fowl diphtheria both in its symptoms and in its etiology but
has nothing corresponding to human diphtheria except its name." membranous croup. 7. The micro-organism of roup (the wet variety or malignant variety) probably lives for a considerable time at least in the earth near the surface ${ }^{4}$ and thus it is readily spread from animal to animal (as well as by direct contact with affected birds). 8. Conditions of soil and surroundings favourable to the spread of diphtheria would likewise appear to favour the spread of roup in fowls. Leeds.

\section{HYDATID CYST IN A NATIVE OF INDIA}

Bx W. J. BUCHANAN, B.A., M.B. Dub.,

MAJOR I.M.S. ; SUPERIN' ENDENT, CENTRAL JAII, BHAGALPUR.

THE following case is published not on account of any clinical interest which it may have, but solely to put on record the fact that hydatid cysts are found, though very rarely, in natives of India who have never left their homes.

A native of the district of Bhagalpur was sent to jail in August, 1896, pending trial for rioting and murder. He complained at once of fever and pain in the right side and was admitted to hospital. On examining him I discovered a large abscess-like tumour in the right flank. No point of fluctuation being found I put in an aspirator needle and evacuated about a pint of highly fœtid thin pus.like fluid. The cavity of the cyst or abscess was then laid open, drained, and washed out with antiseptic lotions. In spite of this the patient did not improve and his temperature remained high (from $102^{\circ}$ to $103^{\prime} \mathrm{F}$.) up to the time of his death two days after. Death, I believe, was due to septic poisoning from the contents of the suppurating cyst. The abscess did not communicate with the peritoneal cavity.

The post-mortem examination made a few hours after death showed a large abscess cavity extending from the midaxillary line, below the costal arch, up to the spinal column. All the other organs were found to be normal, but on removing the liver a yellow-white patch of cartilage-like colour was seen on the upper diaphragmatic surface of the right lobe of the liver. On cutting into this a considerable quantity of thin clear limpid fluid poured out containing numerous small cysts of a mother-of-pearl colour. The parent cyst was about as large as an infant's skull. Recognising it to be an hydatid cyst and knowing the extreme rarity of this affection in natives of India I did not further disturb the parts, but sent the liver to the professor of pathology at the Medical College, Calcutta, Dr. F. J. Drury, who reported to me as follows: "It is undoubtedly an hydatid cyst, containing a number of daughter and granddaughter cysts and rumerous degenerated scolices." The abscess appeared to me to be a cyst which had suppurated. No cysts were found in any other organ.

Though not unknown, it is very rare to find this disease in India. Several cases have been recorded, but generally in Europeans or natives of India who have lived for some time in other countries. There are four specimens in the Calcutta Medical Museum, two from Europeans and two from persons of unrecorded nationality. Dr. Drury found hydatids post mortem in the body of an Eurasian who had lived in Australia. The Lahore Medical College Museum also contains a few specimens, but the nationality of the patients from whom they were taken is not known. Chevers ${ }^{2}$ writes: "Our only evidence that hydatid disease can originate in India rests upon the debatable case of a low caste woman of Bhopal (Central India) who died with bydatids of the spleen." In this case, the woman being of the "sweeper" caste, who take care of and feed dogs, it is easy to understand the source of infection. Other cases are cited by Chevers, but in none of them is there clear evidence that the disease could not have been acquired out of India. It is this point which gives special interest to the present case, for $I$ have ascertained from the deceased patient's family that he never left lis native home except for a few months some years ago when he worked at the Raneegunge coal-mines in a neighbouring district.

The comparative exemption of natives of India from hydatid disease is strange as Dr. Cleghorn many years ago proved that tænia echinococcus very trequently occurred in cattle and sheep slaughtered for food in the Punjab. The same writer even started a theory that many cases of liver

4 I found the Klebs-Loffler mierobe (or one indistinguishable from it) in organically laden soil (see Brit. Med. Jour, A A gust 22nd, 18ऽ6). 
abscess might be due to suppurative changes in hydatid cysts previously existing in the liver. This, however, has never been proved. Davidson in his "Geographical Pathology" makes no mention of India in his account of this disease and, strangely, the articles in Quain's Dictionary on this subject give no details as to the distribution of the parasite. The above case, however, proves beyond a doubt that hydatid cyst can occur in a native of India who has never left his own country.

Bhagalpur.

\section{NOTE ON A NEW MEDIUM FOR THE GROWTH AND DIFFERENTIATION OF THE BACILLUS COLI COMMUNIS AND THE BACILLUS TYPHI ABDOMINALIS.}

\section{BY ALFRED THEODORE MACCONKEY.}

(From the Thompson-Yates Laboratories.)

IN this medium advantage is taken of two well-known facts: (1) that the salts of bile are precipitated by acids, and (2) that bacillus coli communis produces acid in the presence of lactose while bacillus typhi abdominalis does not. The composition of the medium is sodium glycocholate, ${ }^{1} 0.5$ per cent.; peptone, 1.5 per cent.; lactose, 0.3 to 0.5 per cent. ; agar, 1.5 per cent. ; and tap-water, q. s. The lactose is added after filtration.

If stab cultures be made in this medium with bacillus coli communis and bacillus typhi abdominalis and incubated at $42^{\circ} \mathrm{C}$. for from 24 to 48 hours it will be found that the tube inoculated with bacillus coli communis has become cloudy while the tube containing bacillus typhi abdominalis remains quite clear. If glucose be used instead of lactose both tubes become cloudy, but the cloudiness due to bacillus coli communis begins from below and that due to bacillus typhi abdominalis from above. In plates made with the glucose medium incubated for 48 hours at $42^{\circ} \mathrm{C}$. and then left for from three to four days exposed to the light at room temperature the colonies gradually become orange coloured.

Though my experiments are not quite concluded I venture to draw the attention of bacteriologists to this medium because it has a more marked inhibiting effect than carbolised media upon the growth of ordinary soil and water organisms and may prove useful to those who are engaged in examining water, soils, and food-stuffs.

1 The sodium glycocholate was supplied by Messrs. Baird and Tatlock and is, I understand, a mixture of the glycocholate and taurocholate.

The Epileptics at Withington.-The Chorlton Board of Guardians are not at ease about the sane epileptic patients in their charge. From want of accommodation they are at present compelled to occupy the same wards as the imbecile and insane patients. This is obviously a state of things that should be remedied as soon as possible, for to some sane people, even though paupers, such association would be absolutely cruel. Dr. Rhodes said that the guardians were not responsible and that the blame should be laid on the Local Government Board who "were in default through their delay in giving sanction to the scheme which would make provision for these unfortunate people." Other places had the same complaint to make. Few will be found to contradict his further statement that "the methods of the Local Government Board were far too slow." He said he called a few days before at their offices and complained of the manner in which the Board treated the guardians, giving quite "a bit of his mind" to the, no doubt, astonished officials-i.e., if they could be astonished, for by this time such complaints must have lost all their novelty. "He considered the present methods of the Local Government Board were neither satisfactory nor even courteous to the guardians and were certainly not creditable to the former autisority. He hoped the guardians would not further delay the provision of the additional accommodation at Withington workhouse. The treatment of epileptics was a matter concerning not merely the guardians of the Chorlton Union but almost every board in the country."

\section{A}

or

\section{HOSPITAL PRACTICE,}

\section{B RITISH AND FOREIGN.}

Nulla autem est alla pro certo noscendi via, nisi quamplurimas at morborum et dissectionum historias, tum aliorum tum proprias collectas habere, et inter se comparare.-Morgagn De Sed. et Caus. Morb., lib. iv. Procemium.

\section{ROYAL FREE HOSPITAL}

A CASE OF OBSTRUCTION DUE TO NEW GROWTH OF THE SIGMOID FLEXURE; INGUINAL COLOTOMY, FOLLOWED LA'LER BY RESECIION OF THE GROWTH; REESTABLISHAEN'I OF THE INTESIINAL TRAC' ; RECOVERY.

(Under the care of Mr. W. H. BATTLE.)

$A T$ the present day the treatment of malignant growths of the large intestine presents a very great contrast to that which was recognised as advisable even a few years ago. We seldom receive any intimation that a malignant growth is forming in the colon until symptoms of subacute or chronic intestinal obstruction arise. When such a case presents itself what treatment should be followed? Twenty, or even ten, years ago it was customary to remain satisfied with the performance of a colotomy, no attempt even being made to interfere with the primary cause of obstruction. At the present time much better results are obtainable. If the symptoms of obstruction are very severe a preliminary colotomy may be advisable, but in the less acute cases by far the best treatment is to resect the affected portion of bowel and re-establish the intestinal channel.

A man, aged 41 years, was admitted into the Royal Free Hospital on March 11th, 1900, complaining of intestinal obstruction. A fortnight before admission he had severe pain all over the abdomen and on March 1st his bowels were opened, but there had been no motion since, though some flatus had passed. As the abdominal pain steadily grew worse he took to his bed on the 4th. He was treated by a medical man but the pain did not abate. On the 6th vomiting commenced and had continued at intervals; he described the vomited matter as resembling coffee-grounds. He had been able to take nothing but milk and water since the 5th. There was nothing remarkable in his family history.

On admission the patient looked thin and ill ; the abdomen was distended and tympanitic on percussion, but no distinct swelling could be made out and no peristaltic movements were visible. On examination per rectum nothing abnormal was discovered. Obstruction of the large bowel was diagnosed and, in the absence of Mr. Battle, Mr. T. P. Legg, the senior resident medical officer, decided to operate.

The skin of the abdomen having been washed and the patient anæsthetised an incision three inches long was made at right angles to a line drawn from the umbilicus to the anterior superior iliac spine, one-third of the distance from the spine, with the centre of the incision on the line. The incision was deepened until the peritoneum was reached when this bad been incised the large intestine was found and the sigmoid flexure was drawn out into the wound. The bowel was greatly distended and was secured to the edges of the wound by two stitches which did not penetrate the intestinal wall. Another stitch drew together the edges of the incision under the bowel, passing through the mesentery; this was in order to form a well-marked spur. The bowel was then covered with protective and gauze and the wound was dressed. On the next day the patient felt a little better and had no romiting, but the bowels did not act. On March 13th he vomited a little. The intestine was opened and a Paul's tube was inserted for drainage ; his temperature had not exceeded $100^{\circ} \mathrm{F}$. Much frcal matter came away, but he vomited no more. The patient's condition steadily improved and the wound looked well. By April 5th he was allowed to get up every day.

On April 6th Mr. Battle decided to explore the abdomen for the purpose of discovering the cause of the obstruction and removing it if possible. The skin having been cleansed 